\title{
Impact of Pharmacist Provided Counselling to the Parents of Malnutrition Children at Government District Hospital, Kalaburagi, Karnataka
}

\author{
Musku Laxma Reddy ${ }^{1}$, Talikota Yamini ${ }^{2}$, Nallala Pratap Grace Hannah ${ }^{3}$, Mohammad Abdul Shaibaz ${ }^{4}$, \\ Dr. Prasant Borgaonkar ${ }^{5}$, Riyaz Miya ${ }^{6}$

\footnotetext{
${ }^{1}$ Doctor Of Pharmacy, Rajiv Gandhi University of Health Sciences, Bangalore, Karnataka, laxman690[at]gmail.com ${ }^{2}$ Doctor Of Pharmacy, Rajiv Gandhi University of Health Sciences, Bangalore, Karnataka, talikotayamini29[at]gmail.com ${ }^{3}$ Doctor Of Pharmacy, Rajiv Gandhi University of Health Sciences, Bangalore, Karnataka, enoch.gracehannah73[at]gmail.com ${ }^{4}$ Doctor of Pharmacy, Rajiv Gandhi University of Health Sciences, Bangalore, Karnataka,

${ }^{5}$ Department of Pharmaceutics, Rajiv Memorial Educational Society's College of Pharmacy, prashant7522[at]gmail.com ${ }^{6}$ Department of Pharmacy Practice, Rajiv Memorial Educational Society's College of Pharmacy,

*Correspondence: laxman690[at]gmail.com or talikotayamini29[at]gmail.com; Tel:+91-9916849261, +91-7382761525
}

\begin{abstract}
Aim: To assess the nutrition adherence among malnutrition children. To assess the improvement in weight of malnutrition children. Methods: A prospective interventional study was conducted among 98 children for 6 months who were admitted in the District Government Hospital, Gulbarga. Mothers of the children were interviewed and followed by an anthropometric and a clinical examination of the children which includes measuring the patients length, height, weight according to the standards given by the WHO(World Health Organisation) and MUAC using mid upper arm circumference strip based on the results the child's severity of the SAM is determined. The variables studied were age, gender, region, relation between gender and grade, month wise cases collected, comparison of male and female based on month, co-morbidities, relation between co-morbidities and gender, socio-economic status, medical illness in the past months, birth order, breast feeding, immunization status, dietary intake and anthropometric measurements were conducted on malnourished children.. Results: It was found that out of 98 patients, 42 were male, 56 were female, 65 were from Gulbarga and 33 were from other villages. According to grades 3SD and 4SD are more compared to other grades. Among co-morbidities GE and LRTI were found in large numbers compared to other diseases. Conclusion: Pharmacist's plays a vital role, in our study it clearly suggests that pharmacist's counselling to the parents of malnutrition children had improved the child health status than before counselling. Out of 98 undernourished children, 40 children had improved their health status after counselling. So pharmacist plays a vital role in improving the child's nutritional status and health.
\end{abstract}

Keywords: SAM, NRC, SD, PEM, GE, LRTI, MUAC

\section{Introduction}

The term nutrition is derived from a Latin word "nutritic" meaning nourishment. "Mal" means any deviation from normal phenomenon. Malnutrition is defined as any deviation from normal phenomenon. ${ }^{1}$

World health organisation (WHO) defines malnutrition as the cellular imbalance between the supply of nutrients and energy and the body's demand for them to ensure growth, maintenance and specific functions. ${ }^{2}$

Malnutrition is the principal cause of child deaths. Half of all child deaths in India could be prevented if this one issue is tackled. Children die because malnutrition lowers a child's resistance to infection. ${ }^{3}$

"Children are our future, and their mothers are its guardians". Almost 11 million children will die before they reach the age of 5;4 million of them in the first month of life. A large number of them could be prevented by prompting their good health. In India almost one out of every 2 children goes to bed on an empty stomach. ${ }^{4}$

Malnutrition usually occurs when the body is under nourished. This occurs when proper nourishment is not supplied to the body or when the body is unable to obtain nourishment from the ingested food. This condition is mainly due to the presence of medical complication or may be due to the nature of the ingested food. The term marasmus is derived from the Greek word, which means withering or wasting. The term kwashiorkor is taken from the language of Ghana and means the sickness of the weaning. ${ }^{5}$

Forms of Malnutrition:

- Under Nutrition: In sufficient food intake over a extended period of time.

- Over Nutrition: Excessive intake of food over a period of time.

- Imbalance: Disproportion among essential nutrients with or without absolute deficiency of any nutrient.

- Specific deficiency: Relative or absolute lack of an individual nutrient.

\section{Causes \& Consequences of Malnutrition:}

- Malnutrition affects the function and recovery of every organ system.

\section{Muscle function}

Weight loss due to depletion of fat and muscle mass, including organ mass, is often the most obvious sign of malnutrition. Muscle function declines before changes in 


\section{International Journal of Science and Research (IJSR) \\ ISSN (Online): 2319-7064}

Index Copernicus Value (2016): 79.57 | Impact Factor (2015): 6.391

muscle mass occur, suggesting that altered nutrient intake has an important impact independent of the effects on muscle mass. Similarly, improvements in muscle function with nutrition support occur more rapidly than can be accounted for by replacement of muscle mass alone. Down regulation of energy dependent cellular membrane pumping, or reductive adaptation, is one explanation for these findings. This may occur following only a short period of starvation. If, however, dietary intake is insufficient to meet requirements over a more prolonged period of time the body draws on functional reserves in tissues such as muscle, adipose tissue and bone leading to changes in body composition.

\section{Gastrointestinal function:}

Adequate nutrition is important for preserving GI function: chronic malnutrition results in changes in pancreatic exocrine function, intestinal blood flow, villous architecture and intestinal permeability. The colon loses its ability to reabsorb water and electrolytes, and secretion of ions and fluid occurs in the small and large bowel. This may result in diarrhoea, which is associated with a high mortality rate in severely malnourished patients.

\section{Immunity and wound healing:}

Immune function is also affected, increasing the risk of infection due to impaired cell mediated immunity and cytokine, complement and phagocyte function. Delayed wound healing is also well described in malnourished surgical patients. ${ }^{6}$

The classification of SAM can be summarized as follows: [WHO]

- Up to -2SD: Normal

- <-2SD to -3SD: Moderate

- <-3SD: Severe

\section{Signs of Severe Malnutriton:}

1. Severe Wasting

2. Oedema

3. Weigh And Measure The Child

4. Mid Upper Arm Circumference (MUAC)

\section{Methodology}

A prospective interventional study was conducted among 98 children who were admitted in the Department of paediatrics at District Government Hospital, Gulbarga during September 2017 to April 2017.All children who were diagnosed with malnutrition were included in the study. Children who have normal BMI value were excluded from the study.

\section{Results}

The study was conducted among 98 under malnourished children who were admitted in the department of paediatrics at district government hospital, Gulbarga. Out of 98 patients, male patients were 42 and female patients were 56 [table 1], our study shows that girls are at greater risk of higher degrees of malnutrition, might be because of negligence towards the girl child in rural areas of India.

When compared region wise more number of malnourished children was found in Gulbarga were 65 followed by other villages were 33 [table 2] this may be due to migration of labour in search of employment to the district (Gulbarga)

It is clear from our study that the prevalence of malnutrition was high in lesser age group, indicates relatively younger children are the common victims of the malnutrition. Under nutrition in younger age; especially between 1-3 years [table 3] is likely to be due to low energy intake, because children are not feed often with enough household food.

Where as in age-wise distribution 1-2 years that is 41 patients, 2-3 years 24 patients, 3-4 years 13 patients, 4 years above are 14 patients [table 3 ].

Our study which included 98 patients among them 55 patients were with Grade3-SD followed by 4-SD grade patients were 25 [table 4], co-morbidities were 60, and SAM were 38 patients. With Acute GE were 15 patients and SAM with LRTI were 15 patients [table 5].

Table 1: Demographic Profile of Patients

\begin{tabular}{|c|c|c|}
\hline Gender & Number & Percentage \\
\hline Males & 42 & $42.85 \%$ \\
\hline Females & 56 & $57.14 \%$ \\
\hline \multirow{3}{*}{$\begin{array}{ll}\sum^{n} & 60 \\
0 & \\
0 & 40 \\
0 & \\
0 & \\
\vdots & 20 \\
0 & \\
\vdots & 0 \\
z & 0\end{array}$} & \multirow[b]{2}{*}{42} & \multirow[b]{2}{*}{56} \\
\hline & & \\
\hline & male & female \\
\hline
\end{tabular}

Figure 1: Demographic Profile of Patients

Table 2: Demographic Profile of Patients Region Wise

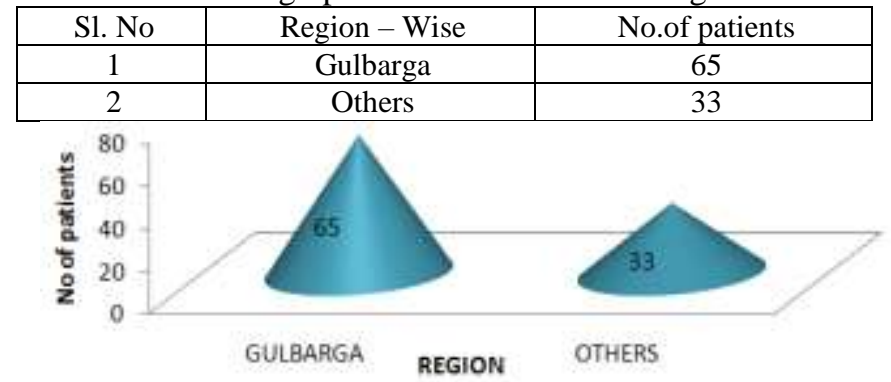

Figure 2: Demographic Profile of Patients Region Wise

Table 3: Demographic Profile of Patients Age Wise Sam Cases Collected

\begin{tabular}{|c|c|c|}
\hline S1. No & Age & No.Of Patients \\
\hline 1 & Below 1 year & 06 \\
\hline 2 & 1-2years & 41 \\
\hline 3 & 2-3 years & 24 \\
\hline 4 & 3-4 years & 13 \\
\hline 5 & 4-5 years & 04 \\
\hline 6 & 5 years \& above & 10 \\
\hline
\end{tabular}




\section{International Journal of Science and Research (IJSR) \\ ISSN (Online): 2319-7064}

Index Copernicus Value (2016): 79.57 | Impact Factor (2015): 6.391

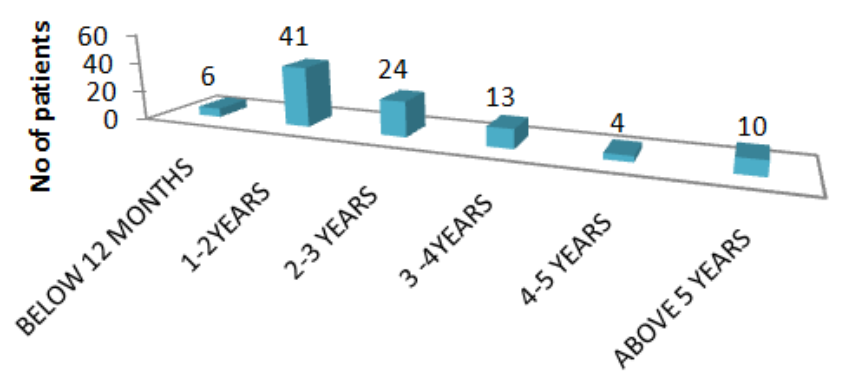

AGE

Figure 3: Demographic Profile of Patients Age Wise SAM Cases Collected

Table 4: Demographic Profile of Patients Showing Distribution of Malnourished Children According To Grades

\begin{tabular}{|c|c|c|}
\hline Sl. No & Grades & No. of Patients \\
\hline 1 & 1SD & 02 \\
\hline 2 & 2SD & 15 \\
\hline 3 & 3SD & 55 \\
\hline 4 & 4SD & 25 \\
\hline
\end{tabular}

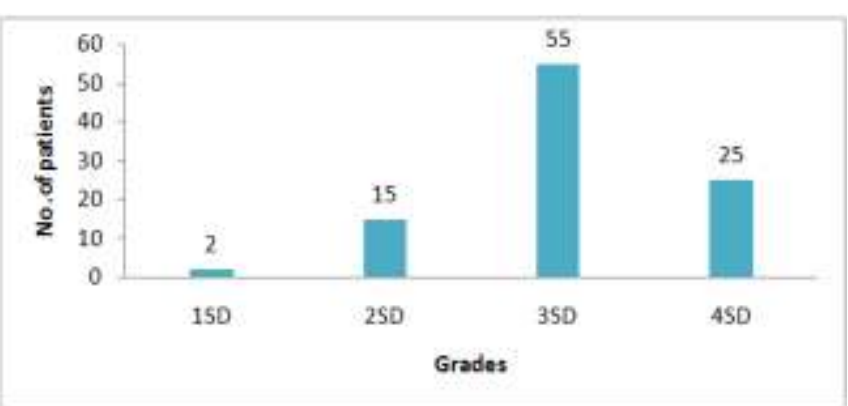

Figure 4: Demographic Profile of Patients Showing Distribution of Malnourished Children According to Grades

Table 5: Demographic Profile of Patients Co-Morbidities

\begin{tabular}{|c|c|c|}
\hline Sl. No & Condition & No. of Patients \\
\hline 1 & Marasmus & 02 \\
\hline 2 & PEM & 04 \\
\hline 3 & LRTI & 15 \\
\hline 4 & Bronchopneumonia & 04 \\
\hline 5 & Coryza & 01 \\
\hline 6 & Bronchiolitis & 01 \\
\hline 7 & Anaemia & 04 \\
\hline 8 & Bronchial asthma & 02 \\
\hline 9 & Acute GE & 15 \\
\hline 10 & RVD & 01 \\
\hline 11 & Measles & 01 \\
\hline 12 & Umbilical hernia & 01 \\
\hline 13 & Rickets & 01 \\
\hline 14 & Down's syndrome & 02 \\
\hline 15 & Enteric fever & 02 \\
\hline 16 & Convulsions & 04 \\
\hline
\end{tabular}

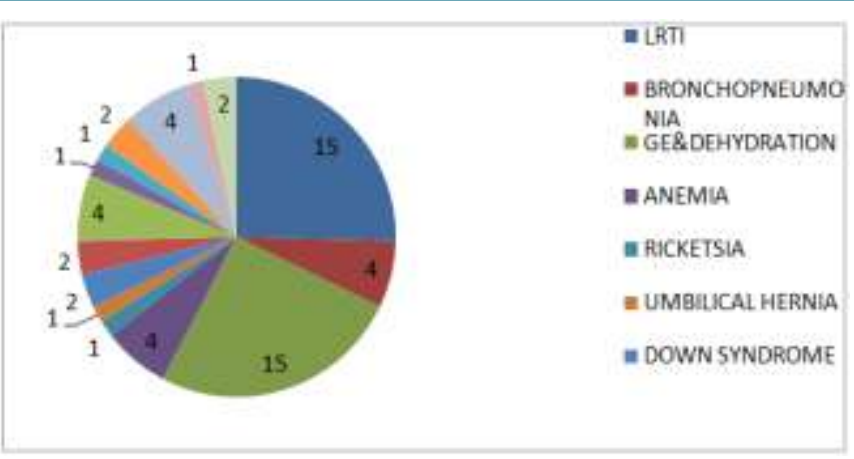

Figure 5: Demographic Profiles Of Patients CoMorbidities

Table 6: Demographic Profile of Patients Improved Health Status after Counselling

\begin{tabular}{|c|c|c|}
\hline \multicolumn{3}{|c|}{ Health Status after Counselling } \\
\hline S1. No & No. Of Patients & $\begin{array}{c}\text { Improved Health } \\
\text { Status After } \\
\text { Counselling }\end{array}$ \\
\hline 1 & 98 & 48 \\
\hline
\end{tabular}

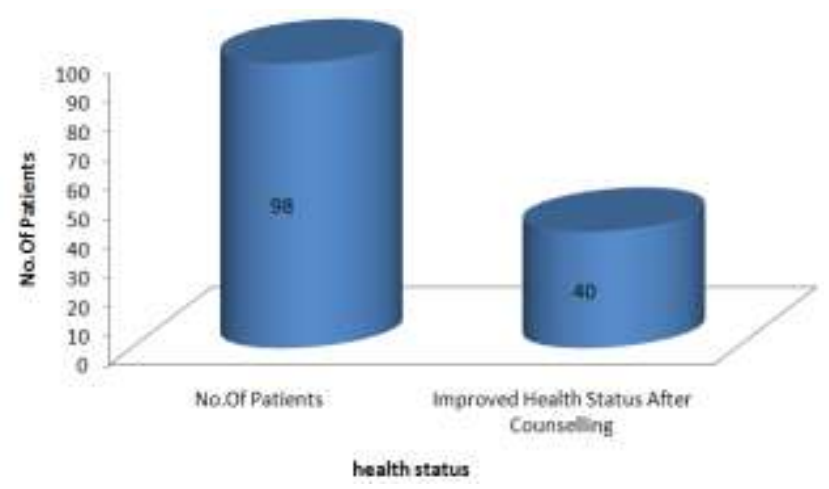

Figure 6: Demographic Profile of Patients Improved Health Status after Counselling

\section{Discussion and Summary}

Our study was conducted to look in to the concept whether pharmacist impact in malnutrition patient's improved or not by counselling to mothers and educating them regarding the good nutrition practices.

Childhood malnutrition is a massive crisis caused by a combination of factors including inadequate food child care practices, childhood diseases, harmful child practices, low socio-economic status, all these contribute to poor health and millions of deaths annually. Malnutrition is like an iceberg, which affected the community both directly and indirectly.

The direct effects are the occurrence of frank and subclinical nutritional deficiency diseases. The indirect effects are high morbidity and mortality among young children.

Out of 98 patients, male patients were 42 and female patients were 56 [table 1], Our study shows that girls are at greater risk of higher degrees of malnutrition, might be because of negligence towards the girl child in rural areas of India. 


\section{International Journal of Science and Research (IJSR) \\ ISSN (Online): 2319-7064}

Index Copernicus Value (2016): 79.57 | Impact Factor (2015): 6.391

When compared region wise more number of malnourished children was found in Gulbarga were 65 followed by other villages were 33[table 2] this may be due to migration of labour in search of employment to the district (Gulbarga).

It is clear from our study that the prevalence of malnutrition was high in lesser age group, indicates relatively younger children are the common victims of the malnutrition. Under nutrition in younger age; especially between 1-3 years [table 3] is likely to be due to low energy intake, because children are not feed often with enough household food.

Where as in age-wise distribution 1-2 years that is 41 patients, 2-3 years 24 patients, 3-4 years 13 patients, 4 years above are 14 patients [table 3].

Our study which included 98 patients among them 55 patients were with Grade3-SD followed by 4-SD grade patients were 25 [table 4], co-morbidities were 60, and SAM were 38 patients. With Acute GE were 15 patients and SAM with LRTI were 15 patients [table 5].

Gastroenteritis is high among the other co-morbidities associated with SAM this is because adequate nutrition is important for preserving GI function. Chronic malnutrition results in changes in pancreatic exocrine function, intestinal blood flow, villous architecture and intestinal permeability. The colon loses its ability to reabsorb water and electrolyte and secretion of ions and fluid occurs in the small and large bowel. This may result in diarrhoea, which is associated with a high mortality rate in severely malnourished patients.

Many Researches show that there is a strong linkage between maternal education and children's health. Children born to educated women suffer less from malnutrition. Malnutrition education has been associated with nutrition outcomes among children in various settings. NFHS-III data also collaborates with these findings. In southern India the incidence rate of malnutrition is high in Karnataka.

In our study it clearly suggests that pharmacist's counselling to the mother's of malnutrition children had improved the child health status than before counselling. Out of 98 under nourished children, 40 children have improved their health status after counselling.[table 6 ] So pharmacist plays a vital role in improving the child's nutritional status and health.

\section{Conclusion}

- Children of relatively younger age from rural areas especially girls are the common victims of malnutrition.

- RTI and acute GE were common co-morbid conditions found among malnourished children. Most of the children were in the early stages of malnutrition, a little extra attention and awareness of parents might definitely help to reduce this problem.

- Our study has found that mothers had poor knowledge on fewer than five nutrition problems and its prevention.
- A significant number of mothers were unaware of the prevention and management of under-five nutritional problems. The knowledge level of the mothers can be empowered with essential health information. This again emphasizes the need to strengthen IEC activities.

- Despite many programs and efforts put down by the government the malnutrition rates still prevail high in the county. The programmes were beneficial only to a certain class of people. We believe that the government should develop a plan in eradicating poverty in the country and providing a strong campaign across the country about the "killer" with real facts and figures, its treatment and its complications. we believe that Malnutrition has drawn the least attention of the leaders to find a solution.

- Nutrition education by the clinical pharmacist and other healthcare professionals to the mothers is essential to help the children grow physically and mentally.

- Clinical pharmacist should make awareness regarding diet which contains more of protein rich foods for nutritional rehabilitation of children with PEM.
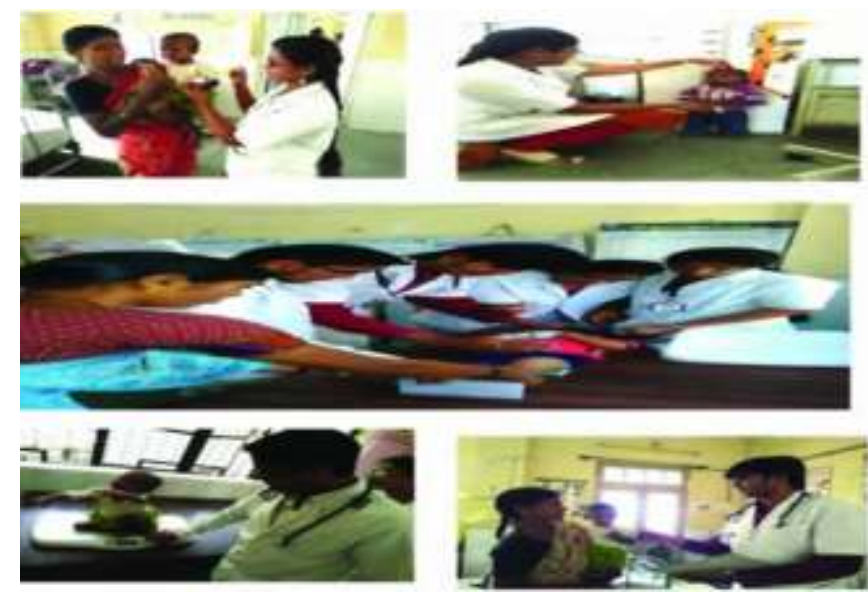

\section{References}

[1] Prakash babu Kodali, et, al. Mid -Day Meal Programme And Adolescent Undernutrition-An Epidemiological Study In Hyderabad, India, Journal Of Pharmacy Practice And Community Medicine.2016, 2(1):16-20.

[2] Alisa Brotherton, Nicola Simmonds and Mike Stroud. Malnutrition Matters Meeting Quality Standards In Nutritional Care. BAPEN Advancing Clinical Nutrition, 2015.

[3] Ravindra.B.Patil, et.al.A Study On Factors Associated With Malnutrition And Risk Of Infections Among Malnourished Children Admitted To McGann Teaching Hospital, Shivamogga, Karnataka, India. Int J Res Med Sci.2015 mar3(3):622-625.

[4] Mangala S. et.al. Epidemiology of Malnutrition among Under Five Children Inrural Area In Karnataka, India. International Journal Of Recent Trends In Science And Technology, volume 9, issue 3, 2014:pp-311-314.

[5] Christie Minj, et.al, Impact Of School Mid-Day Meal Program On The Nutitional Status Of Children In A Rural Area Of South Karnataka, India, International

\section{Volume 6 Issue 12, December 2017}




\section{International Journal of Science and Research (IJSR) \\ ISSN (Online): 2319-7064 \\ Index Copernicus Value (2016): 79.57 | Impact Factor (2015): 6.391}

Journal Of Current Research And Academic Review, Vol 2, No 8 (August -2014)pp.78-84.

[6] Vijayashree Mathad, Shivprasad. S, Malnutrition ; A Daunting Problem For India's Spectacular Growth, Indian Journal Of Clinical Practice, vol, 23, No, 11 April 2013.

[7] Fekadu Alemu. Assessment Of The Impact Of Malnutrition On Children At Dilla Referral Hospital And Paediatric Clinic, Ethiopia. International Journal of Nutrition and Metabolism, 2013; 5:105-113.

[8] Dr.K.Padma, Malnutrition -Incidence And Impact ( A Comparative Study Of Four Southern States In India) International Journal of Humanities And Social Science Invention, Vol:2, Issue.6, June.2013:pp.06-15.

[9] Divya Shettigar, et, al. Assessment Of Knowledge Of Mothers Of Underfive Children On Nutritional Problems: A Rural Community Based Study, National Journal Of Community Medicine, Vol.4, Issue1, Janmar 2013:pp141-144.

[10] Jay M.Mirtallo, Gordon S. Sacks. A Call To Action For An Expanded Pharmacist Role In Influencing The Quality Of Nutrition Care. Journal of Parental and Entaral Nutrition, 2013.

[11] Anoop Paruchuri, Malnutrition In India: A Major Problem With Minor Attention, IJPI's Journal Of Hospital And Clinical Pharmacy, vol 2;9, 2012.

[12] Angan Sengupta, The Changing Face Of Malnutrition In India, Journal of Health Management, 14, 4(2012):451-465.

[13] Sohini Banerjee, et, al. Under -nutrition among adolescents: A Survey in five secondary schools in rural Goa, The National Medical Journal Of India, Vol:24, No.1, 2011:24;8-11.

[14] Ngianga-Bakwin Kandala, Tumwaka P Madungu, Jacques BO Emina, Kikhela PD Nzita and Francesco $\mathrm{P}$ Cappuccio. Malnutrition Among Children Under The Age Of Five In The Democratic Republic Of Congo (DRC): Does Geographic Location Matter.BMC Public Health, 2011; 11:261.

[15]John Saunders. Malnutrition-Causes And Consequences. Clinical Medicine, 2010; 10, (6):6247.

[16] Christine Nesbitt. Children's Right in Urban setting. UNICEF/NYHQ 2008-1027/ Chapter-10.

[17] Monika Blossner, Mercedes de Onis. World Health Organisation Nutrition For Health And Developing Protection Of Human Environment. Geneva 2005.

[18] Olaf Muller, Michael Krawinkel.CMAJ, 2005; 3:173.

[19] Ashworth and Burguss. Caring For Severely Malnourished Children.2003.

[20] Floor Neelemaat, Judith Meijers, Hinke Kruizenga, Hanne van Ballegooijen and Marian van Bokhorst-de van der schueren. Comparison Of Five Malnutrition Screening Tools In One Hospital Inpatient Sample. Journal of Clinical nursing, Blackwell Publishing Ltd, 2001.

[21] Michael C. Latham. Strategies For The Control Of Malnutrition And The Influence Of The Nutritional Sciences.1982; 10

Volume 6 Issue 12, December 2017 www.ijsr.net 